\title{
DEGENERESCÊNCIA HUMANA EM FUNÇÃO DA RAÇA E A FALA PÚBLICA DE JULIANO MOREIRA
}

\author{
Human degenerescence in function of the race and the public speech of Juliano Moreira \\ Isnara Pereira Ivo* \\ Evandra Viana de Freitas**
}

\begin{abstract}
RESUMO: Analisa-se a Fala Pública do médico baiano - o pardo Juliano Moreira - e a contribuição do seu pensamento e ações para o movimento científico, político e social do final do século XIX até o início dos anos 30 do século XX. O discurso acerca da degeneração humana em função da raça, ${ }^{2}$ baseado principalmente em interesses socioeconômicos e culturais, e a emergência de seu contradiscurso, tendo como fundamento a busca do cientificismo biológico na medicina brasileira, são os contextos que conformam a sua atuação em embates contra as teorias deterministas que concebiam os negros africanos como elementos danosos à composição biológica do gênero humano. Em defesa da mestiçagem do povo brasileiro, Juliano Moreira filiou-se ao discurso médico que questionava o racialismo ${ }^{3}$ vigente e, com base em experimentos científicos, comprovou que a degeneração humana teria origens noutras causas e não na mistura entre as raças.
\end{abstract}

Palavras-chave: Juliano Moreira, Degeneração, Raça, Fala Pública.

ABSTRACT: It is analyzed The Public Speech of the Bahian doctor - the brown Juliano Moreira - and the contribution of his thought and actions to the scientific, political and social movement from the end of the 19th century to the beginning of the 1930s. The discourse about human degeneration due to race, based mainly on socioeconomic and cultural interests, and the emergence of his counter-discourse, based on the search for biological scientism in Brazilian medicine, are the contexts that shape his performance in clashes against deterministic theories that conceived black Africans as harmful elements to the biological composition of mankind. In defense of the miscegenation of the Brazilian people, Juliano Moreira joined the medical discourse that questioned the current racialism and, based on scientific experiments, proved that human degeneration would have origins

1 Pesquisa financiada pela Fundação de Amparo à Pesquisa do Estado da Bahia/FAPESB, pelo Conselho Nacional de Desenvolvimento Científico e Tecnológico/CNPq e vinculada ao Laboratório de Estudos da Escravidão e das Mestiçagens da Universidade Estadual do Sudoeste da Bahia.

* Doutora em História pela Universidade Federal de Minas Gerais. Professor Pleno do Departamento de História da Universidade Estadual do Sudoeste da Bahia (UESB) E-mail: naraivo@gmail.com

** Mestre em Memória: Linguagem e Sociedade pela Universidade Estadual do Sudoeste da Bahia (UESB). E-mail: evandravnfreitas@yahoo.com.br

20 termo raça tratado nesse artigo relaciona-se à sua representação em face da sociedade brasileira, com caráter de cunho mais social e político ainda ligado ao conceito antropológico de poligenia do século XIX, que justificou a inferioridade do negro. Acreditava-se na distinção entre as raças humanas como verdadeiras espécies separadas desde às origens e na hierarquização entre elas. Com os estudos contemporâneos acerca da genética molecular das populações (DNA), se constatou que a diversificação morfológica humana é fruto de adaptações às condições climáticas e ambientais das diferentes regiões do mundo, mas que o homem moderno teve origem única e o genoma humano permanece igual (PENA, 2002).

3 O Racialismo é um conceito que decorre da antropologia poligenista, baseado na crença de que existiriam raças biologicamente distintas com diferenças de natureza e de grau. Pregou-se, assim, a ideia de pureza das raças, mas com o pressuposto de que há raças superiores e inferiores e que a mistura entre elas não seria recomendável, sob pena de extinção ou de degeneração. 
in other causes than the mixture between races.

Keywords: Juliano Moreira, Degeneration, Race, Public Speech.

\section{Introdução}

Ao longo do século XIX e até as duas primeiras décadas do século XX, a Medicina se consolidou como um campo do saber capaz de identificar e classificar tanto patologias físicas quanto comportamentais. Intervinha-se de forma preventiva ou terapêtica sobre as doenças e também se prescrevia as condutas - incluindo o campo moral - que os indivíduos deveriam seguir para garantir a defesa das sociedades ante a qualquer fato que pudesse representar uma ameaça à sua ordem interior.

A preocupação dos médicos no Brasil, naquele momento, era com uma possível degeneração das raças (CAPONI, 2014, p. 16), e tal fato deveria ser objeto de política de controle dos governos. Esse anseio e atuação dos cientistas foi posteriormente denominado de biopolítica, conceito criado por Michel Foucault ${ }^{4}$ para explicar a utilização de protocolos médico-científicos como fundamento para a normatização da vida social e política, e que se caracteriza por prescrever o modo de cuidar do corpo e do comportamento na vida em sociedade, estabelecendo orientações, muitas vezes coercitivas, quanto à natalidade, à autorização para conviver em grupo e às questões sanitárias individuais e coletivas ${ }^{5}$. Reprodução, longevidade e mortalidade foram compreendidos como fenômenos relacionados não mais especificamente ao corpo, individualmente, mas às populações e suas formas de viver (CAPONI, 2014, p. 23-24).

Se por um lado a biopolítica propiciou discussões sob o ponto de vista político e social, levando ao reconhecimento e aos cuidados quanto a situações sociais de risco à vida e à proposição de direitos coletivos importantes, por outro, representou a emergência de políticas higiênicas e eugênicas com vistas ao melhoramento e controle das populações a partir de suas raças. Este contexto fomentou a multiplicação de teses sobre as classificações humanas, orientadas por modelos que privilegiavam as características físicas e morais do homem do norte europeu. A degenerescência passou a ser compreendida como o afastamento das características físicas indesejadas, tais como altura, peso, formato do rosto, orelhas, cor da pele, formato das mãos ${ }^{6} \mathrm{e}$, no âmbito moral, à não observância dos valores que a sociedade europeia do século XIX erigia como universais e invioláveis (CAPONI, 2014, p. 26).

As misturas entre as raças, consideradas fatores de degeneração humana, formariam populações deficitárias do ponto de vista físico, intelectual e moral. Assim, a miscigenação biológica

\footnotetext{
${ }^{4}$ Michel Foucault (1926-1984) foi um filósofo, professor, psicólogo e escritor francês contemporâneo, que se dedicou à reflexão entre Poder e Conhecimento. Trabalhou como psicólogo patologista em diversos hospitais psiquiátricos e presídios e, como ativista, se envolveu em campanhas contra o racismo e pela reforma do sistema penitenciário, discutindo todas as formas de aprisionamento humano.

${ }^{5}$ Em 1976, Foucault desenvolveu o conceito de biopolítica em seu História da sexualidade I: a vontade de saber, e nas aulas ministradas no Collège de France, publicadas mais tarde na obra Em defesa da sociedade. A biopolítica começou a se desenhar no século XVIII e se consolidou no século XIX, com o aparecimento de um poder (biologia) que é ao mesmo tempo disciplinador e normalizador e não se exerce mais sobre os corpos individualizados, mas, aliando-se ao Estado, tem pretensões de administrar a vida e o corpo da população. Com este poder, se esquadrinha o nascimento, a mortalidade, o nível de saúde, o comportamento e a longevidade (SOUSA, 2012).

6 Nos sertões das capitanias de Minas Gerais e da Bahia, no século XVIII, as autoridades fiscais usaram desses recursos para classificar os "homens de caminho", que realizavam o comércio entre os sertões do Brasil (IVO, 2012). É possível que essas aplicações signifiquem reminiscências de práticas e usos desses critérios em momentos históricos anteriores (IVO, 2016).
} 
seria potencialmente perigosa para o progresso da humanidade, daí a necessidade do conhecimento e do controle pela ciência sobre a reprodução humana. Tais ideias coadunavam com as do conde francês Artur de Gobineau ${ }^{7}$. Racialista convicto e estudioso das causas da decadência das civilizações, ele afirmava que as raças mestiças herdavam as piores características dos tipos primitivos e, pela força regressiva, estavam fadadas à degeneração e desapareceriam após sucessivas misturas (SOUSA, 2008). Sobre os brasileiros, calculou que o desaparecimento da população mestiça se daria entre duzentos e duzentos e setenta anos.

somos inclinados a acreditar que o número de 270 anos é extremamente exagerado, e que em menos de 200 anos, na verdade, veremos o fim da posteridade dos companheiros de Costa Cabral [sic] e dos imigrantes que o sucederam. Aliás, o Brasil já se acostumou a tal espetáculo. Sem falar das numerosas tribos dos Guaranis, que não deixaram nada mais do que seus nomes no solo que possuíam há bem poucos anos ainda, algumas variedades mestiças, outrora muito conhecidas e capazes de desempenhar um importante papel, já não existem hoje; os mamelucos, por exemplo, do que, aliás, a província do Pará não chega a se lamentar (GOBINEAU, 1873 apud SOUSA, 2008, p. 128-129).

As categorias degeneração, raça e hereditariedade foram incorporadas às discussões científicas entre os teóricos da Medicina e naturalistas ${ }^{8}$ na Europa, nos Estados Unidos da América e também no Brasil. Fizeram emergir uma nova interpretação para as relações sociais, que se intensificaram a partir de 1850 com a aprovação da lei Eusébio de Queiroz (1850). Posteriormente, a Lei do Ventre Livre (1871) e a Lei dos Sexagenários (1885) ${ }^{9}$ podem ser consideradas molas propulsoras para a intensificação dos estudos sobre a degenerescência humana como forma, também, de legitimação das classificações e hierarquizações raciais e sociais vigentes.

Muitos foram os cientistas das mais diversas áreas do conhecimento a se debruçarem sobre as causas das degenerescências, dentre eles, Juliano Moreira. Diferentemente da maioria, Moreira aderiu ao movimento médico organicista alemão para estruturar o campo científico e clínico da Medicina brasileira e refutar as teorias metafísicas que até então explicavam os males físicos e sociais

O entendimento científico, fundamentado no estudo do organismo e o ambiente no qual ele se desenvolve, culminou nas bases da Medicina psiquiátrica, levando à classificação das doenças mentais de Emil Kraepelin ${ }^{10}$, com quem Juliano Moreira estabeleceu estreito intercâmbio científico (DALGALARRONDO, 1996, p. 117-120). O diálogo entre os dois pode ser visto como explicativo para que, com a Fala Pública, Juliano Moreira seja considerado o pai da psiquiatria no Brasil, precursor das práticas de terapia ocupacional, do movimento sanitarista e um dos mais importantes

7 O Conde Joseph Arthur de Gobineau (1816-1882), diplomata e escritor francês, esteve no Brasil como representante de seu governo entre os anos de 1869 e 1870. Seu trabalho escrito mais conhecido é o Ensaio sobre a desigualdade das raças humanas (1855), obra na qual analisa as causas da decadência das civilizações, e que influenciou fortemente o pensamento de estudiosos brasileiros.

8 No século XIX, eram denominados naturalistas os especialistas em história natural, que compreendia os estudos sobre botânica, zoologia, geologia, astronomia e saberes correlatos (ODA, 2003).

9 Legalmente, antecederam a Lei Áurea de 1888, a Lei Eusébio de Queiroz, de 1850, que proibiu a entrada de navios trazendo escravos no Brasil e a Lei do Ventre Livre, de 1871, que considerava livre todos os filhos de mulheres escravas nascidos a partir da data da lei. Porém, como suas mães e pais continuavam em situação de escravidão, a lei estabelecia que as crianças poderiam ficar sob a guarda dos senhores até os 21 anos de idade ou entregues ao governo.

10 Emil Kraepelin (1856-1926) é comumente citado como o criador da moderna psiquiatria e genética psiquiátrica. Kraepelin desenvolveu um sistema de diagnóstico das patologias mentais, e suas teorias sobre a etiologia e diagnóstico de perturbações psiquiátricas são a base dos maiores sistemas diagnósticos utilizados hoje, a exemplo do DSM 5, da Associação Americana de Psiquiatria, e do CID 10, da Organização Mundial de Saúde (ODA, 2001). 
divulgadores das ciências no mundo entre 1891 e 1930.

\section{Juliano Moreira e os fundamentos de sua Fala Pública}

O baiano Juliano Moreira foi médico psiquiatra, cientista, professor, historiador da Medicina, "psicanalista" 11 e agente público. Seu trabalho o tornou intelectual conhecido e reverenciado em diversos países, do Japão até os Estados Unidos da América, passando pelo continente europeu. É reconhecido como referência histórica dos primórdios das ciências psiquiátrica e psicológica, e também da luta contra o racialismo no Brasil.

Embora essa qualificação denote se tratar de um profissional singular e divulgador das ciências e da igualdade entre as pessoas, para a população em geral, o nome Juliano Moreira é apenas uma espécie de personificação do hospital psiquiátrico em Narandiba, Salvador, ${ }^{12}$ ou da colônia para enfermos mentais em Jacarepaguá, no Rio de Janeiro. Mesmo sob este prisma, poucos o conhecem ou sabem da sua importância histórica. No âmbito acadêmico, as pesquisas que o trazem como intelectual focalizam sua contribuição na criação da psiquiatria brasileira e mundial ${ }^{13}$ como saber autônomo. Fora dessa área, entretanto, seu nome, no Brasil, a partir de 1930, é quase desconhecido.

Muito do que se conhece sobre Juliano Moreira se dá a partir da leitura contextualizada dos seus textos e por testemunho de cientistas, médicos, políticos e acadêmicos contemporâneos a ele. Essa opção metodológica de apreensão e descrição do passado é fundamentada no pensamento de Ricoeur $^{14}$ quando ele preconiza que

Une mémoire soumise à l'épreuve critique de l'histoire ne peut plus viser à la fidélité sans être passée au clible de la vèrité. Et une histoire, remplacée par la mémoire dans le mouvement d la dialectique de la rétrospection et du projet, ne peut séparer la vérité de la fidélité qui s'attache em dernière analyse aux promesses non ténues du passé ${ }^{15}$ (RICOEUR, 1998a apud CATROGA, 2015, p. 69).

Juliano Moreira nasceu em 06 de janeiro de 1872, na Freguesia da Sé, cidade de Salvador. Era mestiço de pele preta, livre e pobre. Sua mãe se chamava Galdina Joaquina do Amaral e trabalhava prestando serviços domésticos. A respeito dela, sabe-se que tinha ascendência africana e que não era escrava, apesar de não haver, comprovadamente, referências específicas acerca da sua

\footnotetext{
11 Conforme Neldson Marcolin (2006), de forma pioneira, Juliano Moreira trouxe ao conhecimento dos intelectuais da época, entre 1899 e 1903, o trabalho de Sigmund Freud, traduzido direto do alemão, uma das línguas que dominava.

12 "Aquele ali deve ter fugido do Juliano" é uma frase comumente utilizada pela população de Salvador para indicar que alguém aparenta ter transtornos mentais ou age regularmente como se os tivesse (LYRIO, 2012).

13 Juliano Moreira é o único médico psiquiatra brasileiro a constar no Dicionário Biográfico PSI, do francês Pierre Morel que relaciona psiquiatras, psicólogos e psicanalistas de importância internacional (MOREL apud ODA, 2003).

14 Paul Ricoeur (1913-2005) ficou conhecido como o "filosofo do diálogo". Sua vasta e complexa obra reflete uma tentativa de conciliar criativamente algumas das correntes mais significativas da filosofia contemporânea: a fenomenologia, a hermenêutica, o existencialismo e a psicanálise. Desenvolveu o conceito do "agir ético" como norteador da pessoa na vida privada e pública, indissociavelmente.

15 Tradução livre das autoras: uma memória submetida ao julgamento crítico da história não pode mais visar a fidelidade sem ter sido passada pelo crivo da veridicidade. E uma história, substituída pela memória no movimento da dialética da retrospecção e do projeto, não pode separar a verdade da fidelidade que se prende, em última análise, às promessas do passado.
} 
condição socia $1^{16}$. Seu pai, chamado Manuel do Carmo Moreira, era branco de origem portuguesa e trabalhava como inspetor da iluminação pública municipal. Na certidão de batismo de Juliano (Figura 1), consta somente o nome de sua mãe. O documento permite verificar também que o padrinho de batismo foi o Barão de Itapuã, título que, à época, pertencia ao médico e professor da Faculdade Baiana de Medicina, Adriano Lima Gordilho, para quem a mãe de Juliano Moreira prestava serviços domésticos.

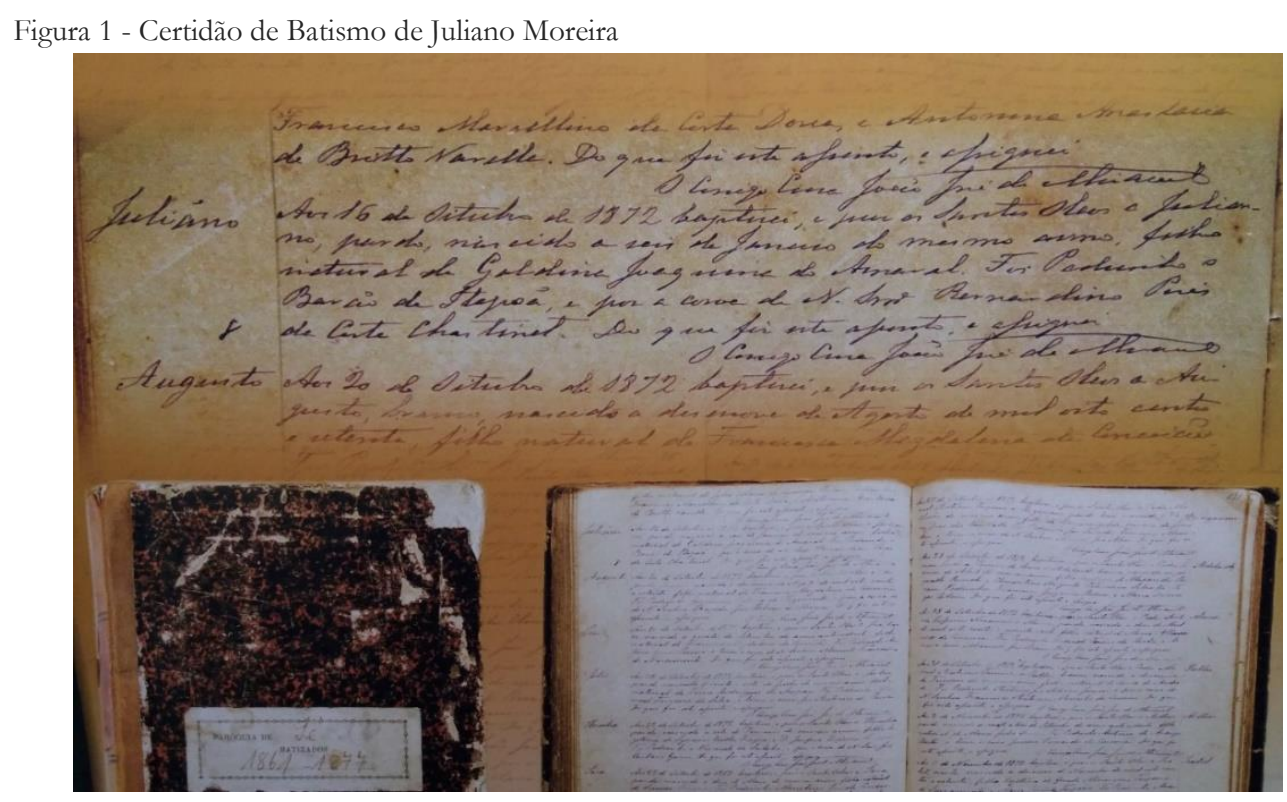

Fonte: fotografado/adaptado pela pesquisadora, do Memorial Juliano Moreira, Salvador, 2018.

Nesse documento está informada a "qualidade"17 de pardo de Juliano Moreira, que nasceu em um Brasil ainda escravocrata, mas já sob a vigência da Lei do Ventre Livre, de 1871. Assim, independentemente, da condição jurídica da sua mãe, ele seria livre. Sob o apadrinhamento do Barão de Itapuã, Juliano Moreira teve acesso aos estudos no Colégio Pedro II, transferindo-se depois para o Liceu Provincial. Em face de sua grande aptidão e conhecimento, lhe foi permitido conciliar os estudos do Liceu com os da Faculdade Baiana de Medicina, na qual ingressou aos treze anos de idade. Cinco anos depois, em 1891, tornou-se doutor em Medicina com apenas 18 anos (JACOBINA, 2008, p. 16).

$\mathrm{Na}$ segunda metade dos Oitocentos, eram amplamente aceitas as ideias sobre a existência de raças humanas biologicamente diferentes e do escalonamento de valor entre elas. A antropologia poligenista, aliada ao darwinismo social ${ }^{18}$, orientou essa concepção, que pressupunha a superioridade dos brancos europeus em relação aos demais povos (SANTOS, 2016, p. 117). Essas ideias se fizeram presentes no Brasil nos contextos das mudanças da organização do trabalho após a abolição

16 Refere-se à condição jurídica de indivíduos e grupos sociais, tais como, livres, forros ou escravos.

17 O conceito de "qualidade", para além da cor da pele, abriga termos/categorias/palavras que aparecem na documentação coeva para se referir a indivíduos e grupos sociais, tais como índios, brancos, pretos, negros, crioulos, pardos, mulatos, mamelucos, mestiços, zambos, cabras, curibocas etc. (IVO; PAIVA, 2008, p. 20; PAIVA et al., 2017, p. 317; IVO e PAIVA, 2016).

18 Embora o conceito seja conhecido como "darwinismo social", trata-se, na verdade, da leitura de Spencer sobre o evolucionismo que, fazendo sua própria interpretação da teoria da evolução de Darwin no campo social, identificava estigmas físicos e morais nos indivíduos e os classificava conforme a viabilidade de desenvolvimento. Sobre essa matéria, recomenda-se A Tribuna da Ciência: as conferências populares da Glória e as discussões do darwinismo na imprensa carioca (1873-1880). (CARULA, 2009) 
da escravidão e as modificações sócio-políticas advindas do fim do regime imperial.

As ressignificações desses preceitos construíram novos discursos, que pretendiam resolver as questões relacionadas aos problemas da então incipiente nação brasileira. A utilização do conceito de raça nas estatísticas oficiais, principalmente no Censo de 1872, pode ser considerada o marco da recepção das ideias cientificistas-racialistas no Brasil. Mas, por força do costume, seriam as tradicionais classificações por categorias de status/cor, tais como, preto, branco, índio, negro que permaneceriam também no vocabulário e nas fontes coetâneas ${ }^{19}$.

As releituras das ideias de raça têm sua origem nos fundamentos dos Estatutos de Limpeza de Sangue, baseados na etnia e na religião que se fizeram presentes desde o Medievo nos países ibéricos e foram adquirindo status legais entre os séculos XV e XVIII. Tais concepções orientavam a identificação, classificação e hierarquização dos povos. De um lado, os limpos de sangue (brancos e cristãos-velhos) e, de outro, aqueles portadores do estigma "raça infecta" (judeus, cristãos-novos, negros mulatos, índios e ciganos $)^{20}$. O ideal de pureza de sangue foi ganhando progressivamente status legal, chegando a vigorar intensamente em Portugal, Espanha e nas suas respectivas colônias, onde foi utilizado como importante elemento de distinção social. A partir do final do século XVIII e no século XIX, as marcas de "impureza" ligadas à noção de raça e ao desvalor da mescla biológica nas sociedades em que as relações econômico-sociais eram baseadas na escravidão do negro africano, como o Brasil, continuaram a fazer parte dos critérios de identificação, classificação e hierarquização de cunho cientificista, eugênico e racialista.

Quando Juliano Moreira se lançou em estudos científicos na defesa da igualdade racial, o Brasil já era reconhecido como um país miscigenado e eram calorosas as discussões acerca do futuro da nação. Esse cenário se deve principalmente à popularização da monografia apresentada por Karl Friedrich Von Martius ${ }^{21}$ no concurso promovido pelo Instituto Histórico e Geográfico Brasileiro (IHGB), em 1840, que premiou o melhor trabalho a respeito de como escrever a história do Brasil ${ }^{22}$. Em seu premiado texto, Martius (1845) propôs que a população brasileira seria formada pela mistura entre três raças, sendo este um dos primeiros registros acerca da composição multirracial como algo peculiar ao Brasil:

são porém estes elementos de natureza muita diversa, tendo para a formação do homem convergido de um modo particular três raças, a saber: a de cor cobre ou americana, a branca ou a caucasiana, e enfim a preta ou etiópia. Do encontro, da mescla, das relações mútuas e mudanças dessas três raças, formou a atual população, cuja história por isso mesmo tem um cunho

19 Ivana Lima (2003) afirmou que a classificação por raça foi usada no censo da Corte de 1848, embora explique que somente a partir do censo de 1872 o conceito assumiu importância nas estatísticas, ainda que no mapa estatístico da província de Sergipe do ano de 1834 a população também tenha sido classificada em função da "cor" e da raça.

200 impedimento a judeus e mouros foi registrado nas Ordenações Afonsinas (1446-1514). As Ordenações Manuelinas (1521-1595) incluíram os ciganos e indígenas. As Ordenações Filipinas (1603 até as aprovações dos Códigos Civis de 1867 e 1926, em Portugal) imprimiram as mesmas restrições aos negros e mulatos. (MATTOS, 2010; OLIVAL, 2004; CALAINHO, 2006).

${ }^{21}$ Karl Friedrich Philipp von Martius (1794-1868) integrou a Missão Austríaca, cuja expedição tinha por objetivo explorar o território brasileiro, percorrendo seus diversos biomas e realizando estudos etnográficos. Radicado por três anos no Brasil, sua vasta produção intelectual dedicou espaço considerável não apenas à fauna e à flora - sua área -, mas também à política, à cultura e à medicina brasileira.

220 texto "Como se deve escrever a História do Brasil", de Martius, venceu o concurso promovido pelo Instituto Histórico e Geográfico Brasileiro (IHGB), em 1840. De natureza sugestiva e inserido em um contexto no qual a constituição de uma origem comum e a busca de um futuro de progresso se tornariam necessários à manutenção e à legitimação de certa conformação social, elaborou um conjunto de princípios e diretrizes norteadores de como se deve pensar uma história nacional no Brasil (GUIMARÃES, 2000). 
muito particular (MARTIUS, 1845, p. 382, grifos nossos).

Em relação à utilização dos termos preta ou etiópia pelo naturalista, é importante registrar que, durante período colonial até meados do século XIX, a descrição de preto foi quase sempre empregada como sinônimo de africano. Segundo Hebe Mattos (2010, p. 154), a designação de preto era também sinônima à de escravo, por correlação e contiguidade desses fatos à época. A documentação coetânea aponta, em alguns casos, que o vocábulo negro apareceu como sinônimo de designativos mais amplos como cor, origem e nascimento. Era mais próximo de uma referência de "qualidade". Mais adiante, os significados se misturaram nos contextos diversos. Pode-se inferir que o vocábulo preto sofreu variações de sentido ao longo do tempo e do espaço, referindo-se, em algumas vezes, à origem e condição (escravo), e em outras, à "qualidade" do indivíduo. As determinações variavam conforme o contexto das dinâmicas de mestiçagens (IVO e SANTOS, 2016, p. 121).

Do texto de Martius (1845), é possível inferir que ele adota a designação preto ou etiópia como aquele que veio de África e se tornou escravo, passando a fazer parte da miscigenação biológica no Brasil. Considerando a mistura entre nativos, europeus e africanos, o naturalista consolidou institucionalmente essa visão sobre a população brasileira. O que chama a atenção no excerto é que, sem mencionar as outras duas raças, ele traz um questionamento apenas sobre qual seria a contribuição dos pretos na formação da população mestiça brasileira:

não há dúvida de que o Brasil teria tido um desenvolvimento muito diferente sem a introdução dos escravos negros. Se para o melhor ou para o pior, este problema se resolverá para o historiador, depois de ter tido ocasião de ponderar todas as influências, que tiveram os escravos africanos no desenvolvimento civil, moral e político da presente população (MARTIUS, 1845, p. 397, grifos nossos).

Neste extrato da monografia de Martius (1845), há uma sutil menção à escravidão dos índios. Ao mencionar "a introdução dos escravos negros", o autor sugere a existência de outros escravos no território brasileiro anterior ou concomitantemente. Mas o foco dele é na questão da incorporação do preto nas misturas biológicas, e a expressão "se para o melhor ou para o pior", tornou-se um dos fundamentos das discussões acerca das teorias deterministas na sociedade brasileira naquele período (VENTURA, 2000, p. 13).

Nesta discussão, nomes expressivos expuseram o seu pensamento, a exemplo de Silvio Romero $(1894)^{23}$, que, ao rearticular a teoria da degeneração humana, acreditava ser possível utilizar a miscigenação biológica entre as raças para branquear os brasileiros. Defensor das políticas de branqueamento para diluir o sangue negro e indígena nas gerações futuras, Romero (1894) afirmava que existiriam duas grandes desigualdades na humanidade: as classes e as raças, sendo as primeiras filhas da história, e as segundas, filhas da natureza.

Abolicionista e republicano, entendia que a democratização dos povos poderia dar fim à diferença de classes. Em relação às raças, no entanto, apoiava a ideia de diferença de grau e defendeu um esforço científico e governamental para o "mestiçamento" progressivo rumo ao branqueamento.

23 Sílvio Vasconcelos da Silveira Ramos Romero (1851 -1914) foi um crítico literário, poeta, ensaísta, pesquisador de folclore, filósofo e também agente público na categoria de deputado federal, quando ajudou a redigir o Código Civil Brasileiro. Dentre sua vasta obra, destacamos: Doutrina contra doutrina; o evolucionismo e o positivismo no Brasil de 1894. 
A distincção e desegualdade das raças humanas é um facto primordial e irreductivel, que todas as cegueiras e todos os sophismas dos interessados não têm fôrça de apagar. É uma formação que vai entroncar-se na biologia e que só ella póde modificar. Esta desegualdade originaria, brotada do laboratório immenso da natureza, é bem differente da outra diversidade, oriunda da historia, a distincção das classes sociaes (ROMERO, 1894, XXII).

E, "respondendo" à questão posta por Martius (1845), sugeriu que o preto teria contribuído para o pior da formação da população, sendo necessário diluir seu sangue, incorporando novos elementos por meio da imigração de europeus. Suas ideias foram compartilhadas por vários intelectuais da época, incluindo seu contemporâneo, o abolicionista Joaquim Nabuco (1849-1910), que afirmou:

um país onde todos sejam livres, onde, atraída pela franqueza de nossas instituições e pela liberdade do nosso regímen, a imigração europeia traga, sem cessar, para os trópicos uma corrente de sangue caucásico vivaz, enérgico e sadio, que possamos absorver sem perigo [...]; um país que de alguma forma trabalhe originalmente para a obra da humanidade e para o adiantamento da América do Sul (NABUCO, 2000, p. 101, grifo nosso).

Os debates se fizeram representar também nas artes plásticas. É bem conhecido o quadro A Redenção de Cam (Figura 2), de Modesto Brocos y Gomes ${ }^{24}$, que simboliza esse desejo do branqueamento do brasileiro para viabilizar um "melhor" futuro para a nação.

Figura 2 - A Redenção de Cam

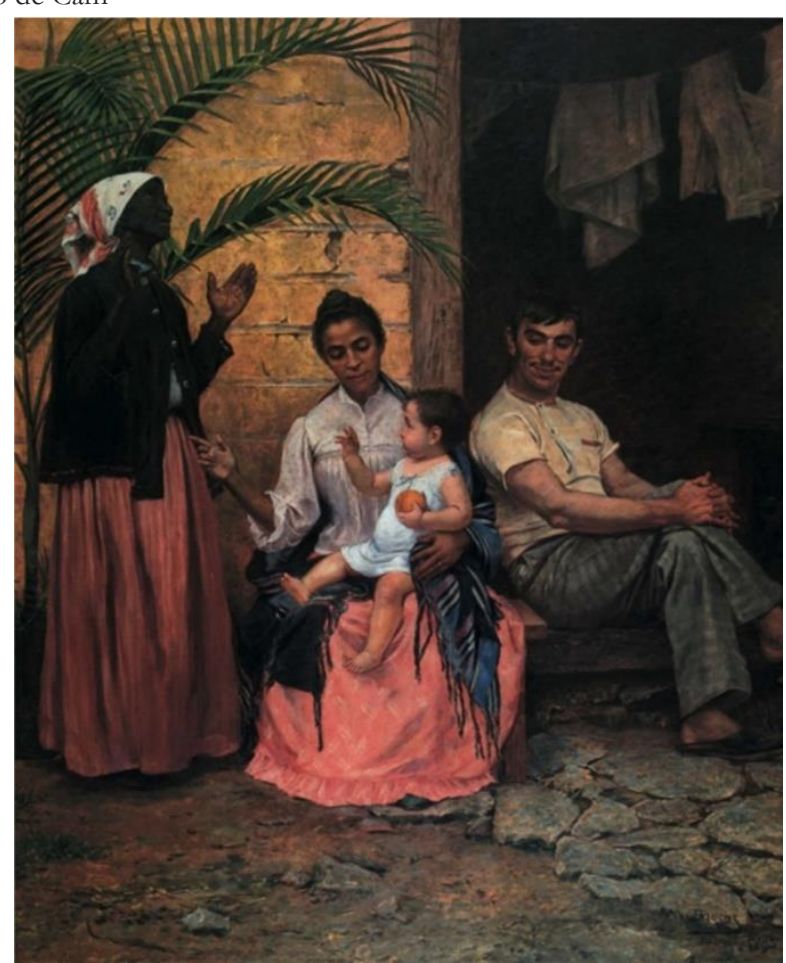

Fonte: Pintura de Modesto Brocos y Gomes A Redenção de Cam (1895), óleo sobre tela, 199cm x 166cm. Rio de Janeiro. Museu Nacional de Belas Artes. Imagem extraída de Lotierzo (2017).

24 (1852-1936), pintor espanhol, naturalizado brasileiro na década de 1890. Sobre o tema do branqueamento e o mito "os filhos de Cam" na historiografia, recomendamos a leitura de Uma história do branqueamento ou o negro em questão (HOFBAUER, 2006) e Contornos do (In)visível: Racismo e Estética na Pintura Brasileira (1850-1940). (LOTIERZO, 2017). 
Destoando em relação às propostas de branqueamento de parte da intelectualidade brasileira, Nina Rodrigues, um racialista conhecedor da tese das degenerescências e das teorias eugenistas, defendia a diferença biológica entre as raças e se posicionou em importante trabalho sobre a responsabilidade penal do preto no Brasil25, quanto à questão incitada por Martius (1845):

O conflicto, - que se estabelece no seio do organismo social pela tendencia a fazer, á força, iguaes perante a lei e seus effeitos, raças realmente tão distinctas e desiguaes -, tem o seu símile e se deve realisar no seio do organismo individual, nos casos de mestiçamento em um mesmo individuo qualdades physicas, physiologicas e psychicas, não só distinctas, mas ainda de valor muito differente no ponto de vista do conceito evolutivo do aperfeiçoamento humano (RODRIGUES, 2011, p. 132).

Nesses embates, o trabalho científico de Juliano Moreira também trouxe ao campo intelectual e político um novo posicionamento sobre as questões de miscigenação e degenerescência: as condições precárias e insalubres da população. Com temas que se tornaram topoi da classe médica e dos governos na República, os esforços pessoais e científicos de Juliano Moreira foram na contramão do pensamento majoritário vigente, para combater a ideia de uma diferença irredutível e de hierarquia entre as raças.

Juliano Moreira foi aluno de Nina Rodrigues e depois seu colega na Faculdade de Medicina da Bahia, onde defendeu ideias contrárias ao seu mestre. Afirmou que a degenerescência existia sim na espécie humana, porém as causas não eram advindas da miscigenação biológica, mas estavam relacionadas às questões ambientais, comportamentais e hereditárias, que podiam explicar as incidências de problemas degenerativos. Para ele, o trabalho do médico não deveria ser influenciado por "ridículos preconceitos de cores ou castas", pois os inimigos a serem combatidos eram o alcoolismo, a sífilis, as verminoses e as precárias condições sanitárias e educacionais no Brasil (MOREIRA, 1922 apud DALGALARRONDO; ODA, 2000, p. 178).

A Fala Pública de Juliano Moreira, aliada à sua práxis, começa a fazer História junto a jovens médicos e políticos. Com seus seguidores, influenciou o movimento sanitarista, que teve seu auge em 1920. Sua principal atuação, porém, foi através do conjunto de ações promovidas nas políticas públicas de tratamento de pessoas com transtornos psiquiátricos, quando esteve à frente do hospital Nacional dos Alienados, no Rio de Janeiro, entre 1903 e 1930.

Juliano Moreira defendia a ideia de que não é possível explicar a produção e a circulação de conhecimentos sem buscar as realidades nas quais encontra-se imerso o sujeito e as circunstâncias (ALMEIDA, 2006, p. 5). O percurso e a Fala Pública de Juliano Moreira fundamentam-se, além da escola organicista alemã, no trabalho de Bénédict $\mathrm{Morel}^{26}$ acerca das degenerescências psíquicas, intelectuais e morais na espécie humana. Seus estudos foram sistematizados em um tratado como uma forma de compreender os mecanismos de degradação da natureza humana originária ${ }^{27}$.

A teoria de Morel (1857) surgiu como uma das tentativas de resposta para as muitas questões acerca do indivíduo e da sociedade, quando se buscou consolidar o saber científico como caminho para compreender a realidade humana. Se opunha à visão dos naturalistas, quanto ao

\footnotetext{
25 Em seu livro As raças humanas e a responsabilidade penal no Brasil (1894), afirma que os negros seriam uma raça inferior e sem possibilidade de alcançar o patamar evolutivo do branco europeu em razão de sua constituição orgânica diferente.

26 1809-1873.

27 Traité des dégénérescences physiques, intelectuelles et morales de l'espèce humaine et des causes qui produisent ces variétés maladives (Tratado das degenerescências psíquicas, intelectuais e morais na espécie humana e as causas que produzem essas morbidades), de 1857.
} 
determinismo climático e de mesclas, colocando-se também contrário ao diagnóstico baseado em estigmas (SERPRA JR. 2010; CAPONI, 2014). Acreditava numa pluralidade de causas para as degenerescências, dentre elas o abuso do álcool, a alimentação deficiente, o meio social miserável e insalubre, a imoralidade dos costumes, a conduta sexual desregrada e as doenças da infância. Considerava ainda a importância da herança de uma carga de degenerescência dos ascendentes. Ele defendia, portanto, que a degenerescência era adquirida e transmitida sucessivamente, quando não estancadas as razões ambientais e os comportamentos danosos que levavam a lesões nos organismos, aliando-as às predisposições hereditárias.

O discurso de Juliano Moreira também abordava esses fatores como causadores das degenerações na população brasileira, especialmente o alcoolismo, as condições insalubres de moradia e a fadiga ocupacional. $\mathrm{Na}$ esteira de uma releitura organicista da teoria das degenerescências de Bénédict Morel, com filiação às proposições de políticas profiláticas gerais, Juliano Moreira tornouse um dos precursores, se não o precursor, da mudança do discurso médico acerca da não influência das raças na degeneração da população brasileira.

Como o francês, apresentou em seus trabalhos científicos propostas relacionadas ao modo de vida e às condutas humanas. No contexto de uma medicina normatizadora, atacou o alcoolismo, o comportamento social desregrado, a prostituição e o casamento (reprodução) entre pessoas doentes, atribuindo a esses atos humanos o mesmo valor crítico que conferia à falta de políticas públicas de saneamento e educação. Combatendo as teorias deterministas que creditavam à miscigenação os problemas físicos e sociais, denunciava os comportamentos individuais, coletivos e institucionais que colocavam em risco a integridade do organismo social brasileiro. Nesse sentido reafirmava com veemência que, enquanto não se mudasse o discurso e a práticas das autoridades em relação aos problemas sanitários do Brasil, os problemas identificados não seriam solucionados.

\section{Fala Pública, ações e resultados}

No Brasil, seguindo o modelo dos países da Europa ocidental, a Retórica constituiu-se em uma verdadeira instituição na segunda metade do século XIX, tornando-se instrumento das cátedras da Medicina e dos representantes do nacionalismo emergente ligados aos vários saberes (SOUZA, 2015, p. 187-188). Sem pretender adentrar nas minúcias dos estudos da Linguística e da Filosofia, tomamos aqui a referência aristotélica que compreende a construção e exposição de ideias num discurso a ser levado a público, articulando o uso da lógica ou "espírito da razão" (logos); a percepção que o público tem sobre a autoridade de que discursa (ethos) e, em especial, as emoções de quem recebe a mensagem (pathos).

Os embates acerca das teorias deterministas do Oitocentos têm essa construção de logos, ethos e phatos. Seja como ciência ou como crença, as ideias previamente pensadas e organizadas eram expostas em cátedras, conferências, reuniões, livros e periódicos, com vistas ao convencimento e à adesão. A fala humana deixa de ser a prática espontânea de interação e se transveste em um instrumento público no exercício da autoridade, revelando múltiplas relações de força entre os membros e os grupos de uma sociedade. Fenômeno histórico e fato social que remonta à Antiguidade, o qual passamos a reconhecer conceitualmente como Fala Pública (SILVA, 2018, p. 201).

Essa prática de persuasão é encontrada historicamente em diversas culturas antigas. Para fins deste trabalho, tomamos como referência histórica da Fala Pública o pensamento de Aristóteles (384 -322 a. C.), que concebe a Retórica como uma forma de comunicação fundamentada em princípios e técnicas, com vistas ao convencimento do outro e ligados ao bem agir socialmente, 
politicamente e historicamente. Significa dizer que a arte de falar ao público pressupõe o pensar bem e o fazer bem na vida privada e na conduta pública. Não basta apenas ter o talento de encadear ideias de forma lógica e fundamentada, mas, antes de tudo, ter um modo de vida compatível com aquilo que é levado ao público (LIMA, 2011, p. 10). Neste fundamento, estaria o poder de persuadir o outro a aderir a uma ideia e levar ao movimento de mudança ou à aceitação de uma situação determinada.

Aristóteles se via diante de uma sociedade ameaçada por posturas egoístas, confusas e de desarticulação coletiva. Neste contexto, concebeu a Retórica acreditando que, na construção e ordenação dos discursos a serem proferidos pelo indivíduo virtuoso, levando em conta a situação social, o ambiente, e as pessoas envolvidas, poderia persuadir os demais a adotarem uma nova forma de ordenação social. Pela Retórica, era possível conjecturar o bem-estar da polis e o aprimoramento da eupraxia, termo grego que significa o bem agir em conformidade com o justo e o verdadeiro (LIMA, 2018, p. 14).

A Fala Pública está intimamente ligada às formas de se nortear condutas gerais e manter ou substituir valores sociais, éticos e políticos, em cada tempo e lugar. $\mathrm{Na}$ Idade Média, tendo como método a pregação religiosa, era materializada em sermões às comunidades que buscavam reforçar o controle do comportamento individual e familiar por meio da fé cristã, muitas vezes, guiada pelo medo do castigo. Durante a Revolução Francesa, a Fala Pública se popularizou desligando-se em parte das figuras de representatividade formais e aproximando-se do conceito de República (coisa pública). Com a revolução, a fala ganhou novo corpo enquanto fato social: o seu aspecto popular e participativo. Não era mais apenas o de receptor, mas o de indivíduo ativo na produção do discurso revolucionário (SILVA, 2018, p. 202). A população participou do processo revolucionário por meio dos centros de opinião externos ao espaço parlamentar formal de poder, proporcionando espaços novos de difusão das Falas Públicas.

Na última parte do Oitocentos, no Rio de Janeiro, dois espaços foram idealizados por intelectuais que desejavam persuadir o público a aderir à corrente científica ou ideológica sócio-política: as Conferências Populares da Glória e os cursos públicos do Museu Nacional (CARULA, 2009 , p. 27). Nesses lugares ${ }^{28}$, buscava-se envolver todas as camadas da sociedade, em um ambicioso projeto de mudança de mentalidade ao transmitir o conhecimento científico produzido na Europa e popularizar a ciência na sociedade brasileira. Ali os temas ligados à ciência e também questões de natureza social e política eram expostos.

Ao longo da história humana, a Fala Pública de qualquer um que estivesse investido de alguma autoridade, deveria ser entendida como instituição promotora de Fato Social, vez que a contraposição entre aquele que fala e aquele que ouve, assim como os silenciamentos de um ou de ambos, expõem as relações sociais de força que se pretendem legítimas e gerais, de acordo com a autoridade do emissor e o lugar social do ouvinte. A Fala Pública, oral, escrita, ou ainda o silêncio da autoridade é aqui tomada como fato social porque contém em si os poderes e os perigos dos discursos (COURTINE; PIOVEZANI, 2015, p. 15/22), capazes de produzir políticas de convívio nos âmbitos social, econômico e cultural, estabelecendo relações de dominação ou de emancipação.

Instituindo um Fato Social na contramão das ideias vigentes, a Fala Pública de Juliano Moreira, entre os anos de 1891 e 1933, conseguiu modificar consensos acerca das ideias de degeneração em função da raça e alcançou uma extensa produção científica, tornando-o um divulgador das

28 As reuniões se tornaram um evento social para população ouvir e aprender com as autoridades médicas do momento. 
ciências no Brasil e no mundo, além de proporcionar fundamentos para mudanças de políticas públicas. Seu interesse nas pesquisas científicas e na popularização de conceitos científicos já existia em seus tempos de estudante. Em 1890, quando era acadêmico do quinto ano, foi aprovado no concurso interno do Serviço Clínico de Dermatologia e Sifiligrafia da Faculdade Baiana de Medicina. Neste período, também já mantinha contato com os médicos da Escola Tropicalista Bahiana, que trouxe a Medicina experimental para o Brasil, revolucionando a forma de conhecer e tratar diversas patologias.

Em 1891, com sua tese Etiologia da syphilis maligna precoce, recebeu não só o título de bacharel, mas também o de doutor em Medicina (JACOBINA, 2014, p. 438). Com estudo inaugural, em que obteve nota máxima, se tornou referência bibliográfica em outros países, inovou a pesquisa científica, estudando e enumerando todas as possíveis causalidades da sífilis, além de fazer comparações com populações de outras partes do planeta. Suas conclusões permitiram-lhe refutar cientificamente a tese da influência climática e racial na gênese e na malignidade da sífilis. Na parte final da tese, constatou, em Fala Pública escrita, utilizando o recurso linguístico da ironia para fazer perguntas retóricas e apontar suas reflexões sobre os conceitos vigentes: ' $E$ ' assim que a questão das raças continua a ser origem de dissidência dos competentes. Quantas são as raças? Onde começa a raça branca? Onde começa a amarela? Onde acaba? Onde começa a preta?” (MOREIRA, 1891, p. 136).

Utilizando o estudo científico em sua luta para mudar paradigmas vigentes, Juliano Moreira demonstrou na irônica frase do seu texto, os resultados encontrados ao final sua pesquisa: a inexistência de pureza de raça. Tal fato o fez levantar discussões para outros pontos que entendia ser os verdadeiros motivos das degenerescências dos brasileiros, quais sejam: as más condições de vida da população mais pobre, a falta de educação sanitária, o alto grau de analfabetismo e os comportamentos "desregrados" da população. O alcoolismo, o uso de outros tóxicos e a prostituição constituíam os outros males sociais que podiam afetar a reprodução humana e a preservação da espécie. Esses elementos podiam causar, sim, a degenerescência humana, caso não fossem sanados pelas intervenções médicas da saúde pública.

Quando Juliano Moreira foi aprovado no concurso público para professor da Faculdade de Medicina da Bahia, em 1896, apresentou um discurso que pode ser considerado como sua primeira grande manifestação pública oral sobre a questão da miscigenação biológica do brasileiro, especialmente em relação às pessoas negras. Entre os notáveis da Academia, estudantes e jornalistas, a essência da sua Fala Pública, que causou grande repercussão, foi afirmar, que:

a quem se arreceie que a pigmentação seja nuvem capaz de marear o brilho desta Faculdade [...]. Em dias de mais luz e hombridade o embaçamento externo deixará de vir à linha de conta. Ver-se-á, então, que só o vício, a subserviência e a ignorância são que tisnam a pasta humana quando a ela se misturam ganhando-lhe o íntimo e aí inviscerando o mal [...]. A incúria e o desmazelo que petrificam, a hipocrisia, a baixeza e a desfaçatez que desmoralizam, sim, dão a massa humana aquele outro negror que a torna incapaz de fornecer radiações (LYRIO, 2012, p. 43 , grifo nosso).

Juliano Moreira condensou suas ideias sobre a miscigenação biológica face à teoria da degenerescência, entendendo-a sob outro prisma ${ }^{29}$. $\mathrm{Na}$ esteira da ideia popularizada pela monografia de Martius (1845) sobre os elementos étnicos formadores da população brasileira, afirmou que

29 Notícia sobre a evolução da assistência a alienados no Brasil. Archivos Brasileiros de Psychiatria, Neurologia e Sciencias Affins. Revisão de Ana Maria G. R. Oda. Rio de Janeiro, vol. 1, n. 1, 1905, p. 52-98. 
Portugal primeiro desafogou seus presídios, trazendo para cá sua população mais embrutecida e, posteriormente, foi buscar na África milhões de pretos, os quais explorou da maneira mais degradante, para construir a economia. Nesta perspectiva, mencionando as péssimas condições das travessias no atlântico, retomou uma questão aceita por ele há muito tempo:

O álcool representou nesse bárbaro processo de colonização o maior papel imaginável. Com ele procuraram aumentar a pacatez das vítimas, mas simultaneamente foram-se-lhes infiltrando nos neurônios os elementos degenerativos que, reforçados através do tempo, dão a razão de ser de muita tara atual atribuída à raça e à mestiçagem por todos aqueles que não querem se dar ao trabalho de aprofundar as origens dos fatos (MOREIRA, 1905, p. 729).

De forma rara nos discursos médicos de então, Juliano Moreira considerou a população indígena como pertencente ao processo de miscigenação biológica, asseverando que também os índios foram aproveitados à custa de álcool e miçangas. Finalizou afirmando que os europeus trouxeram ao Brasil o alcoolismo, a sífilis, a lepra, a tuberculose e, esquecidos desta questão, atribuíam a degeneração humana à raça preta e à miscigenação. Sentenciou que, pelas vias da educação e da produção de um meio social saudável, os indivíduos poderiam se constituir como moralmente iguais e passíveis de serem influenciados por uma moralidade civilizadora. As diferenças, para ele, estariam somente na dimensão físico-orgânica. Investido de sua autoridade de agente público, em sua Fala Pública esclareceu uma profunda preocupação ética sobre os comportamentos visarem ao crescimento pessoal e ao bem comum, o que ilustrava o discurso médico normatizador presente entre o final do século XIX e as primeiras décadas do XX (VENANCIO, 2004, p. 290).

O caráter versátil, criativo e múltiplo de Juliano Moreira (JACOBINA, 2008) fez dele um médico tropicalista (experimentalista) que descreveu os aspectos clínicos e sociais em sua luta contra a malária no interior da Bahia, e fez uma revisão crítica do papel dos mosquitos na transmissão desta patologia em seus estudos clínicos sobre o beribéri e a doença do sono. Suas pesquisas sobre a leishmaniose cutâneo-mucosa no Brasil foram das primeiras registradas. Foi dermatologista e sifilógrafo e também neurologista e psiquiatra estudioso da epilepsia, das mioclonias em pessoas histéricas $^{30}$ e não histéricas, e de um novo tipo de assistência aos alienados ${ }^{31}$. As pesquisas nessas áreas eram incipientes inclusive na Europa e a suas intervenções soavam como luz na escuridão sobre males que a Medicina ainda não conseguia explicar e tratar.

Os desdobramentos práticos da Fala Pública de Juliano Moreira podem ser verificados quando ele se tornou formulador de planejamento e administração em saúde, participando da proposta de reforma do Asilo São João de Deus, em Salvador, e dos estudos sobre o asilo-colônia em Juqueri, em São Paulo. De forma pioneira, defendeu a criação de serviços de anatomopatologia e de laboratórios nos hospitais do Brasil. No Rio de Janeiro, assumiu a direção do Hospital Nacional dos Alienados, local no qual trabalhava e residia.

O hospital tornou-se então uma "escola", pois Juliano Moreira recebia uma gama de estudantes e colegas ávidos por novos conhecimentos e para fazer parte da construção da história médica e política do país. Por suas argumentações e demonstrações clínicas nos grupos de estudos,

\footnotetext{
30 Histeria é um distúrbio psicológico que afeta homens e mulheres, peça-chave para compreensão do pensamento Freudiano, aborda as somatizações em que síndromes psíquicas provocam sintomas físicos não detectáveis em exames do corpo.

31 O termo "alienado" está contextualizado no sentido semântico da área da psiquiatria do final do século XVIII e século XIX. Pinel o utiliza desde 1797 para caracterizar o estado dos doentes mentais, substituindo o termo "loucura", considerado por ele como genérico.
} 
tornou-se um professor sem cátedra. Um fragmento iconográfico (Figura 3) da trajetória de Juliano Moreira denota a notoriedade que teve até 1930 e que legitimava sua autoridade e discurso acerca das políticas médicas, sanitaristas e humanitárias.

O respeito às ideias de Juliano Moreira ultrapassou as fronteiras do Brasil e chegou aos grandes centros de estudos da Europa e do Japão. Em breve visita ao Brasil, em 1925, Albert Einstein compareceu à Academia Brasileira de Ciências, então presidida pelo psiquiatra brasileiro, que o convidou para conhecer o Hospital Nacional de Alienados. De acordo com as notas jornalísticas, Einstein pediu para observar um caso de "paranoia legítima", influenciado talvez pelo triste destino de seu filho mais novo, Eduard ${ }^{32}$. O físico teórico ficou particularmente interessado pelas oficinas terapêutico-ocupacionais apresentadas pelo médico baiano (JACOBINA, 2008).

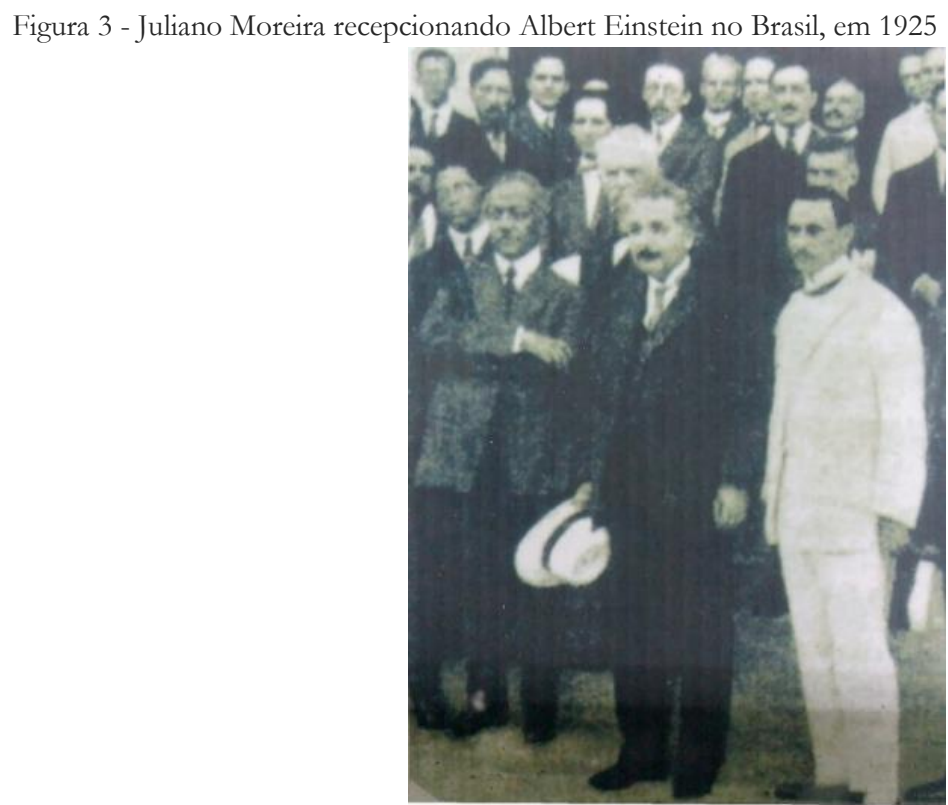

Fonte: fotografado pela pesquisadora no Memorial Juliano Moreira, Salvador, 2018. Juliano Moreira está à esquerda de Albert Einstein, vestindo terno escuro.

Juliano Moreira já era cientista e agente público renomado quando participou do Congresso Jubilar da Société de Médecine Mentale da Bélgica, onde foi aclamado membro honorário. Em sua longa viagem de visita a Tóquio, Kioto, Sendai, Hokaído, Osaka e Funoko, no ano de 1928, recebeu a insígnia da "Ordem do Tesouro Sagrado", entregue pelo Imperador do Japão e destinada aos "consagrados da ciência mundial", por defender a imigração de japoneses para o Brasil. Em 1929, tornou-se membro honorário da Sociedade de Neurologia e Psiquiatria de Berlim, da Sociedade Médica de Munich e da Cruz Vermelha Alemã. No mesmo ano, em Hamburgo, quando foi eleito membro da Sociedade de Neurologia e Psiquiatria, lhe foi conferida, pela Universidade local, a Medalha de Ouro, a mais alta honraria prestada a um professor estrangeiro (Figura 4).

32 O jovem foi diagnosticado com esquizofrenia. Os tratamentos utilizados na época pioraram sua situação e a terapia eletroconvulsiva teria afetado fortemente sua memória e habilidades cognitivas. 
Figura 4 - Juliano Moreira em Hokaido e Fuoka, Japão, em Hamburgo, Alemanha e no Egito
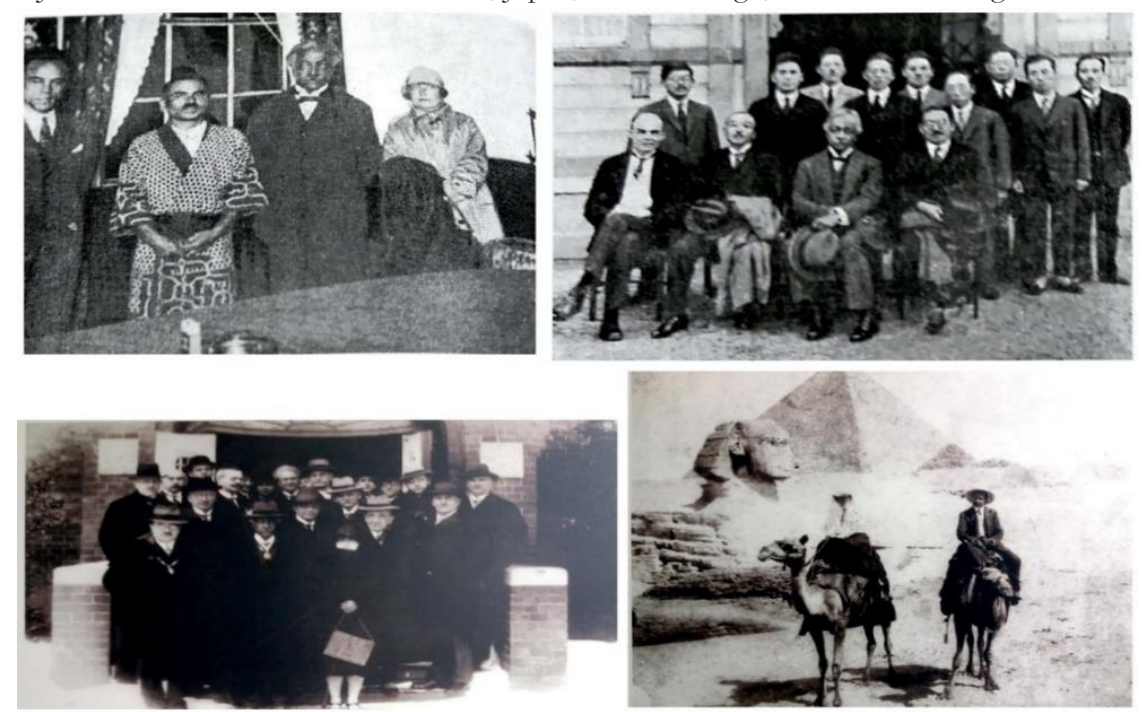

Nota: Respectivamente canto superior esquerdo (1928), superior direito, inferior esquerdo (1929) e inferior direito.

Fonte: fotografado e adaptado pela pesquisadora. Memorial Juliano Moreira, Salvador, 2018

Uma das últimas Falas Públicas de Juliano Moreira foi trazida ao público brasileiro por sua esposa, a enfermeira alemã Augusta Peick, a pedido de Gilberto Freyre. Trata-se de um extrato da tese defendida pelo médico em 1929, na Faculdade de Medicina de Hamburgo, na Alemanha, na qual reafirmara o seu posicionamento contrário à ideia de degenerescência pelas misturas entre as raças:

no Brasil não existem differenças profundas entre os individuos de origens diversas. As differenças por mim encontradas dependem mais do grau de instrucção e de educação de cada um dos examinados do que do grupo ethnico a qual elle pertence. Assim é que individuos pertencentes a grupos ethnicos considerados inferiores, quando nascidos e creados em grande cidade, apresentavam melhor perfil psychologico, do que individuos mesmo provindo de raças nordicas, creados no interior do paiz em um meio atrasado. E' em todo caso certo que um individuo retirado cedo de um meio social inferior e levado a um ambiente melhor, desenvolve-se de modo surpreendente se não houve em seu cérebro falha anatomica congenita (FREYRE, 1937, p. 150).

A repercussão de suas ideias, no campo da medicina e da educação sanitarista no início do século XX, deriva de um intenso trânsito científico e cultural com vários países, especialmente Alemanha, Japão e França. Sua Fala Pública geradora de fato social contribuiu decisivamente para o movimento inicial de enfrentamento da teoria da degenerescência social no final do século XIX, e para a disseminação de um pensamento em favor das mestiçagens biológicas da população brasileira. Marcadamente, foi partícipe ativo da implantação de um poder biopolítico que vige nas sociedades modernas e contemporâneas desde o século XIX, com seus avanços técnicos e idas e vindas éticas, culturais e sociais, permeado por memórias de poder.

\section{Considerações finais}

O trabalho de Juliano Moreira trouxe ao campo científico e político questões relacionadas à miscigenação, à degeneração, à formação da nação, às condições precárias e insalubres da população, dentre outros temas que se tornaram topoi da classe médica e dos governos na Primeira 
República. Construiu uma atuação emergente na biopolítica no Brasil e seu posicionamento foi de combate às teorias do determinismo racial, clamando para o fato de que o meio social saudável era a medida de prevenção contra as degenerescências humanas e não as misturas entre as raças.

Negou cabalmente a correlação entre as degenerescências e a constituição racial, demonstrando, desde a sua tese Etiologia da Syphilis Maligna Precoce, que aquelas decorriam de outros fatores causais, como o alcoolismo e as condições insalubres e a falta de educação sanitária que assolavam a maior parte da população, especialmente a urbana.

Rearticulando os conceitos de Bénédict Morel, se tornou um dos precursores do movimento sanitarista que culminaria na criação, no Brasil, do Instituto de Higiene, em 1920, e da Liga Brasileira de Higiene Mental, em 1922. Com sua fala e prática - Fala Pública - visava mostrar a igualdade das raças, defendendo medidas para a melhoria da educação e do meio social, com vistas a incluir o Brasil e sua população miscigenada num projeto de desenvolvimento e progresso. Para ele, não havia diferença hierárquica entre as raças, as possíveis diferenças seriam físico-orgânicas individuais, comprovadamente independentes do clima e da raça. Sua Fala Pública alcançou status normatizador, influenciando comportamentos, regras e modos pensar.

\section{Referências}

ALMEIDA, Maria da Conceição Xavier de. Narrativas de uma ciência da inteireza. In: SOUZA, Elizeu Clementino de (org.). Autobiografias, histórias de vida e formação: pesquisa e ensino. Porto Alegre: EDIPUCRS; Salvador: EDUNEB, 2006. p. 02-14.

CALAINHO, Daniela Buono. Agentes da fé: familiares da Inquisição portuguesa no Brasil Colonial. Bauru, SP: Edusc, 2006.

CAPONI, Sandra. Loucos e degenerados: uma genealogia da psiquiatria ampliada. Rio de Janeiro: Editoria Fiocruz, 2014.

CARULA, Karoline. A Tribuna da Ciência: as conferências populares da Glória e as discussões do darwinismo na imprensa carioca (1873-1880). São Paulo: Annablume Editora, 2009.

CATROGA, Fernando. Memória, história e historiografia. Rio de Janeiro: Editora FGV, 2015.

COURTINE, Jean-Jacques; PIOVEZANI, Carlos. História da fala pública - uma arqueologia dos poderes do discurso. Editora Vozes. 2015.

CUNHA, Euclides. Os Sertões - Campanha de Canudos. São Paulo: Montecristo Editora. 2012. Disponivel em: < https://asdfiles.com/29Tk>. Acesso em: 23 set. 2018.

DALGALARRONDO, Paulo. Civilização e Loucura: uma introdução à História da Etnopsiquiatria. São Paulo: Lemos, 1996.

DURKHEIM, Émile. As regras do método sociológico. 17. ed. Tradução de Maria Isaura Pereira de Queiroz. São Paulo: Companhia Editora Nacional, 2002.

FOUCAULT, Michel. Microfísica do Poder. Rio de Janeiro: Graal, 1989.

FREYRE, Gilberto. Novos estudos afro-brasileiros. II Tomo. Rio de Janeiro: Civilização Brasileira S/A, 1937.

GUIMARÃES, M. L. S.: História e natureza em von Martius: esquadrinhando o Brasil para construir a nação. História, Ciências, Saúde - Manguinhos, vol. VII(2), 389-410, jul.-out. 2000.

HOFBAUER, A. Uma história do branqueamento ou o negro em questão. São Paulo: Editora UNESP, 2006

IVO, Isnara Pereira. Homens de caminho: trânsitos culturais, comércio e cores nos sertões da América portuguesa. Século XVIII. Vitória da Conquista: Edições Uesb, 2012.

. Seria a cor, a qualidade, a condição ou o fenótipo? Uma proposta de revisão dos critérios 
de distinção, classificação e hierarquização nas sociedades ibero-americanas. In: IVO, Isnara Pereira e PAIVA, Eduardo França. Dinâmicas de mestiçagens no mundo moderno: sociedades, culturas e trabalho. Vitória da Conquista: Edições Uesb, 2016. pp. 19-44.

e SANTOS, Ocerlan Ferreira. Mestiçagens e distinções sociais nos sertões da Bahia do século XIX. Revista de História Regional 21(1): 110-129, 2016. Disponível em: <http://www.revistas2.uepg.br/index.php/rhr>

JACOBINA, Ronaldo Ribeiro; GELMAN, Ester Aida. Juliano Moreira e a Gazeta Médica da Bahia. História, Ciências, Saúde - Manguinhos, Rio de Janeiro, v. 15, n. 4, out./dez. 2008, p. 1077-1097. Nem clima nem raça: a visão médico-social do acadêmico Juliano Moreira sobre a sífilis maligna precoce. Revista Baiana de Saúde Pública, v. 38, n. 2, abr./jun. 2014, p. 432-465.

LIMA, Ivana Stolze. Cores, marcas e fala: sentidos da mestiçagem no Império do Brasil. Rio de Janeiro: Arquivo Nacional, 2003;

LIMA, Marcos Aurélio de A retórica em Aristóteles: da orientação das paixões ao aprimoramento da eupraxia. Natal: IFRN, 2011.

LYRIO, Alexandre. Juliano Moreira: o terapeuta do afeto. Salvador: Edições Alba, 2012.

LOTIERZO, Tatiana. Contornos do (In)visivel: Racismo e Estética na Pintura Brasileira (1850-1940). São Paulo. Edusp, 2017.

MARCOLIN, Neldson. O alienista. Revista Pesquisa Fapesp. Edição 124, jun., 2006. Disponível em: <http://revistapesquisa.fapesp.br/2006/06/01/o-alienista/>. Acesso em: 20 jun. 2016.

MARTIUS, Karl Friedrich Von. Como se deve escrever a história do Brasil. Revista Trimestral do Instituto histórico e geographico brasileiro, vol. 06, n. 24, 1845, p. 381- 403. Disponível em: $<$ http://brasilindependente.weebly.com/uploads/1/7/7/1/17711783/von_mar-

tius_como_se_deve_escrever_a_historia_do_brasil_1845.pdf >. Acesso em: 25 jul. 2018.

MATTOS, Hebe Maria. Escravidão e cidadania no Brasil monárquico. Rio de Janeiro: Jorge Zahar, ed., 2000.

. A escravidão moderna nos quadros do Império português: o Antigo Regime em perspectiva atlântica. In: FRAGOSO, João L. R; BICALHO, Maria Fernanda; GOUVEIA, Maria de Fátima (Org.) 0 Antigo Regime nos Trópicos: A dinâmica imperial portuguesa (séculos XVI-XVIII). Rio de Janeiro: Civilização Brasileira, 2010. p. 143-162.

MOREIRA, Juliano. Etiologia da Syphilis Maligna Precoce. 1891. Tese (Doutoramento em Medicina) - Faculdade de Medicina de Bahia, Salvador, 1891.

Notícia sobre a evolução da assistência a alienados no Brasil. Archivos Brasileiros de Psychiatria, Neurologia e Sciencias Affins. Revisão de Ana Maria G. R. Oda. Rio de Janeiro, vol. 1, n. 1, 1905, p. 52-98.

MOREL, Benedict-August. Traité des dégénérescences physiques, intelectuelles et morales de l'espèce humaine et les causes qui produisent ces variétés maladives. Paris: Baillière, 1857. Disponível em: < https://archive.org/details/traitdesdg57more/page/n9 >. Acesso em: 06 out. 2018.

NABUCO, Joaquim. O Abolicionismo. São Paulo: Publifolha, 2000. (Grandes nomes do pensamento brasileiro da Folha de São Paulo). Disponível em: <http://www.dominiopublico.gov.br/download/texto/bv000127.pdf $\geq$. Acesso em: 30 maio 2018.

ODA, Ana Maria Galdini Raimundo. A teoria da degenerescência na fundação da psiquiatria brasileira: contraposição entre Raimundo Nina Rodrigues e Juliano Moreira. Psychiatry on line Brasil, v. 6, n. 12, dez. 2001.

Alienação Mental e Raça - a psicopatologia comparada dos negros e mestiços brasileiros da obra de Raimundo Nina Rodrigues. 2003. 438f. Tese (Doutoramento em Ciências MedicasSaúde Mental) - UNICAMP, São Paulo. Disponível em: < http://repositorio.unicamp.br/handle/REPOSIP/311615>. Acesso em: 14 ago. 2017 
OLIVAL, Fernanda. Rigor e interesses: os estatutos de limpeza de sangue em Portugal. Cadernos de Estudos Sefardistas, n. 4, p. 151-182, 2004. Disponível em: http://www.catedra-alberto-benveniste.org/_fich/15/artigo_Fernanda_Olival.pdf. Acesso em janeiro de 2016.

PAIVA, Eduardo França. Dar nome ao novo: uma história lexical da Ibero-América entre os séculos XVI e XVIII (as dinâmicas de mestiçagens e o mundo do trabalho). Belo Horizonte: Autêntica, 2015. PASSOS, Alexandre. Juliano Moreira (vida e obra). Rio de Janeiro: Livraria São José, 1975.

PENA, Sergio D. J. (org.). Homo brasilis: aspectos genéticos, linguísticos, históricos e socioantropologicos da formação do povo brasileiro. São Paulo: FUNPEC-RP, 2002

POLI, Maria Cristina. Alienação" na psicanálise: a pré-história de um conceito. Psychê. Ano IX. n. 16, São Paulo. Jul./dez. 2005, p. 133-152.

RODRIGUES, RN. As raças humanas e a responsabilidade penal no Brasil[online]. Rio de Janeiro: Centro Edelstein de Pesquisa Social, 2011, 95p. ISBN 978-85-7982-075-5. Available from SciELO Books <http://books.scielo.org>.

ROMÉRO, Sylvio. Doutrina contra Doutrina - o evolucionismo e o positivismo na República do Brasil. $1^{\text {a }}$ série. Rio de Janeiro: Editor J. B. Nunes. 1894.

SOUSA, Kátia Menezes de. Discurso e biopolítica na sociedade de controle. In TASSO, I.; NAVARRO, P. (org.). Produção de identidades e processos de subjetivação em práticas discursivas [online]. Maringá: Eduem, 2012. p. 41-55. Disponível em: <http://books.scielo.org/id/hzj5q/pdf/tasso9788576285830-03.pdf>. Acesso em: 26 out. 2018.

TAMANO, L. T. O. O movimento sanitarista no Brasil: a visão da doença como mal nacional e a saúde como redentora. Khronos, Revista de História da Ciência, n4, pp. 102 - 115. 2017. Disponível em <http://revistas.usp.br/khronos>. Acesso em 11/07/2020.

VENANCIO, Ana Teresa A. Doença Mental, Raça e Sexualidade nas Teorias Psiquiatras de Juliano Moreira. PHYSIS: Rev. Saúde Coletiva, Rio de Janeiro, 14 (2), 2004, p. 281-305.

VENTURA, Ricardo. Estilo tropical: história cultural e polêmicas literárias no Brasil, 1870-1914. $2^{\text {a }}$. reimpressão. São Paulo: Companhia das Letras, 2000.

Artigo recebido em: $19 / 05 / 2020$

Artigo aceito em: 26/07/2020 